\title{
Assessing energy performances: A step toward energy efficiency at the municipal level
}

\author{
Francesca Poggi ${ }^{\mathrm{a}, *}$, Ana Firmino ${ }^{\mathrm{a}}$, Miguel Amado ${ }^{\mathrm{b}}$

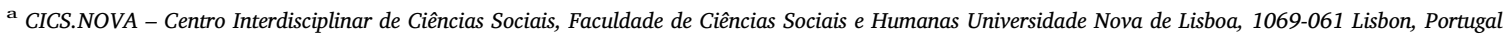 \\ b 2: CERIS-Civil Engineering Research and Innovation for Sustainability, Instituto Superior Técnico, Universidade de Lisboa, 1049-001 Lisbon, Portugal
}

\section{A R T I C L E I N F O}

\section{Keywords:}

Energy efficiency

Local planning

GIS

Spatial models

Municipal master plan review

Municipal energy performances

\begin{abstract}
A B S T R A C T
At present, energy efficiency represents one of the foremost challenges to achieve the transition toward a lowcarbon society. Reducing energy use spans a broad range of technical issues and spatial scales: from building to districts, from cities to rural areas, and from energy power plants to electricity grids. In this frame, the challenge of enhancing energy efficiency can be understood as an extremely relevant topic for planning at the municipal level. Nevertheless, recent studies provide evidence that significant gaps exist in the enhancement of energy efficiency within municipal boundaries. The present research recognises that a comprehensive assessment of municipal energy performances is an essential starting point to facilitate local planning in enhancing energy efficiency. However, how can this challenge be translated into practice and applied to the implementation of local planning? As new models result from the transformation of existing ones, the development of a methodology associated with a case study in Portugal was deemed the most appropriate approach to contribute to knowledge in these fields. The primary objective of this study is to move toward more integrated process of planning for energy efficiency, supporting the definition of priorities and strategies to address energy saving improvements at municipal level. The assessment process involves a statistical analysis that using Geographical Information System, is combined and translated into spatial models to determine needs and set priorities within a Municipal Master Plan review. Based on this top-down approach, it becomes clear that energy efficiency is a cross-cutting issue interrelated with a blend of various disciplines: geography, spatial planning, urbanism, architecture, and civil engineering. The results enable us to understand why municipalities should be called upon to enhance energy efficiency by first looking at a comprehensive energy performance assessment. Embracing the whole municipal territory rather than only urban areas, is key to articulate energy efficiency and geographical, social, environmental and economic factors that are at the core of local planning.
\end{abstract}

\section{Introduction}

From the Brundtland Report in 1987 to the 2015 Paris Climate Conference - COP21, international concern has been expressed regarding how best to combat global warming to achieve more sustainable development. One of the lessons learned from these three decades of reflexive debates is that "environment-development" and "climate-energy" represent two bilateral relationships, interconnected in a critical cause-and-effect loop. Energy is a driving force for modern civilization development (Afgan, Gobaisi, Carvalho, \& Cumo, 1998). Since the Industrial Revolution, however, economic and population growth, underpinned by globalization and capitalism processes, has increased emission of greenhouse gases, primarily stemming from fossil fuel combustion and land use changes (Clack \& York, 2005). Thus, the threat of global climate change arises as an outcome of progress and social conquests (Laughlin, 2012) in a blend of "burn out", "collapse" and "overshoot" catastrophic scenarios, as noted by Rob Hopkins (Hopkins, 2008; Neves \& Leal, 2010; Hopkins, 2008:33). Sustainable development and energy must progress together, bringing about a desired transition towards the efficient energy use and the switch to renewables, (Boyle, 2012; García-Álvarez, Moreno, \& Soares, 2016; Hopkins, 2008; Süsser, Döring, \& Ratter, 2017;).

In this framework, Smart Cities (Calvillo, Sánchez-Miralles, \& Villar, 2016), Net-Zero Energy Buildings (Kolokotsa, Rovas, Kosmatopoulos, \& Kalaitzakis, 2011), Internet of Things (Atzori, Iera, \& Morabito, 2016), Information and Communications Technologies (Battarra, Gargiulo, Pappalardo, Boiano, \& Oliva, 2016) represent significant solutions being implemented, but, they currently result in planning approaches mainly focused on urban contexts.

\footnotetext{
* Corresponding author.

E-mail addresses: f.poggi@fcsh.unl.pt (F. Poggi), am.firmino@fcsh.unl.pt (A. Firmino), miguelpamado@tecnico.ulisboa.pt (M. Amado).

URL: http://cics.nova.fcsh.unl.pt/ (F. Poggi).
} 
The multi-dimensionality of energy transition (Sovacool \& Geels, 2016) leads us to consider a global energy balance equation in which planning for both energy efficiency, i.e. less consumption, and renewable energy, i.e. a cleaner supply, has to move beyond urban boundaries to focuses on the whole energy system (Poggi, Firmino, \& Amado, 2015). There is growing consensus that local scale and cross-scale dynamics play an important role in addressing and understanding energyenvironmental issues (Pasimeni et al., 2014). Here, energy efficiency is a key aspect of rethinking cities and territories, in light of the local planning process (Mirakyan \& De Guio, 2013).

Nevertheless, a literature review provides evidence that significant gaps exist in the form of enhancing energy efficiency within municipal boundaries. Reducing energy use spans a broad range of technical issues and spatial scales: from building to districts, from cities to rural areas, and from energy power plants to electricity grids. In this frame, the challenge of enhancing energy efficiency can be understood as an extremely relevant topic for planning at the municipal level. The value of this perspectives is an effective sustainable management of resources that integrates energy needs in a comprehensive territorial planning strategy (Cosmi et al., 2015).

This ways of thinking confirms what Patrick Geddes wrote in 1915 on "Survey Before Plan (Süsser et al., 2017:340)", "the collaboration of rustic and urban points of view, of county and rural authorities (Süsser et al., 2017:352)" and "the full utilisation of local and regional conditions (Süsser et al., 2017:352)". These arguments provide highly topical insights on the relevance of local action and top-down and bottom-up approaches to planning. Geddes's theories seem to be important for enhancing energy sustainable planning so long as this challenge shows itself to be less and less the result of single initiative and more the kind of a local planning action. Following Geddes' thought, this paper aims to contribute to the debate on why enhancing energy efficiency at the local scale and the importance of the "survey before plan" concept in this process. The main objective behind the energy performance assessment carried out in Arraiolos (Portugal) is to give directions to the Municipal Masterplan (MMP) review. This step aims to set up an adequate framework for a planning process capable of enhancing energy efficiency among different municipal domains and spatial scales: the functional allocation of economic activities, on the basis of a potential balance between energy consumption and production; the association of energy savings, firstly, with local bioclimatic conditions and urban forms and morphologies and, secondly with building types and materials; the modernization of electricity system through smart technologies; and planning grid expansion, considering topological optimization within new and existing urban areas.

\section{Framework}

Energy efficiency constitutes a strategic development vector in rapid evolution, with different sectors as its target, namely, population behaviour (Jia, Srinivasan, \& Raheem, 2017), transportation (Karan, Mohammadpour, \& Asadi, 2016), industry (Abdelaziz, Saidur, \& Mekhilef, 2011), agriculture (Li, Baležentis, Makutenienè, Streimikiene, \& Kriščiukaitienė, 2016) and the building/construction sector (Gellings, 2009). Indeed, energy efficiency is currently being promoted through several approaches, such as public awareness programmes, measures aimed at the construction of new buildings and improvement of existing ones (Ruparathna, Hewage, \& Sadiq, 2016), sustainable mobility solutions (Goldman \& Gorham, 2006), and the reconfiguration and renewal of local planning process for the territory (Bulkeley \& Betsill, 2005; Rosa \& Neves, 2010). Without neglecting any of the aspects mentioned, the present research seeks to contribute to the last category. This section aims to review the theoretical and practical approaches that are currently related to the task of enhancing energy efficiency at municipal scale.

The review process was based on the analysis of peer-reviewed studies published between 2003 and 2017 and indexed by Scopus and ISI Web of Knowledge databases. According to an inductive approach, 

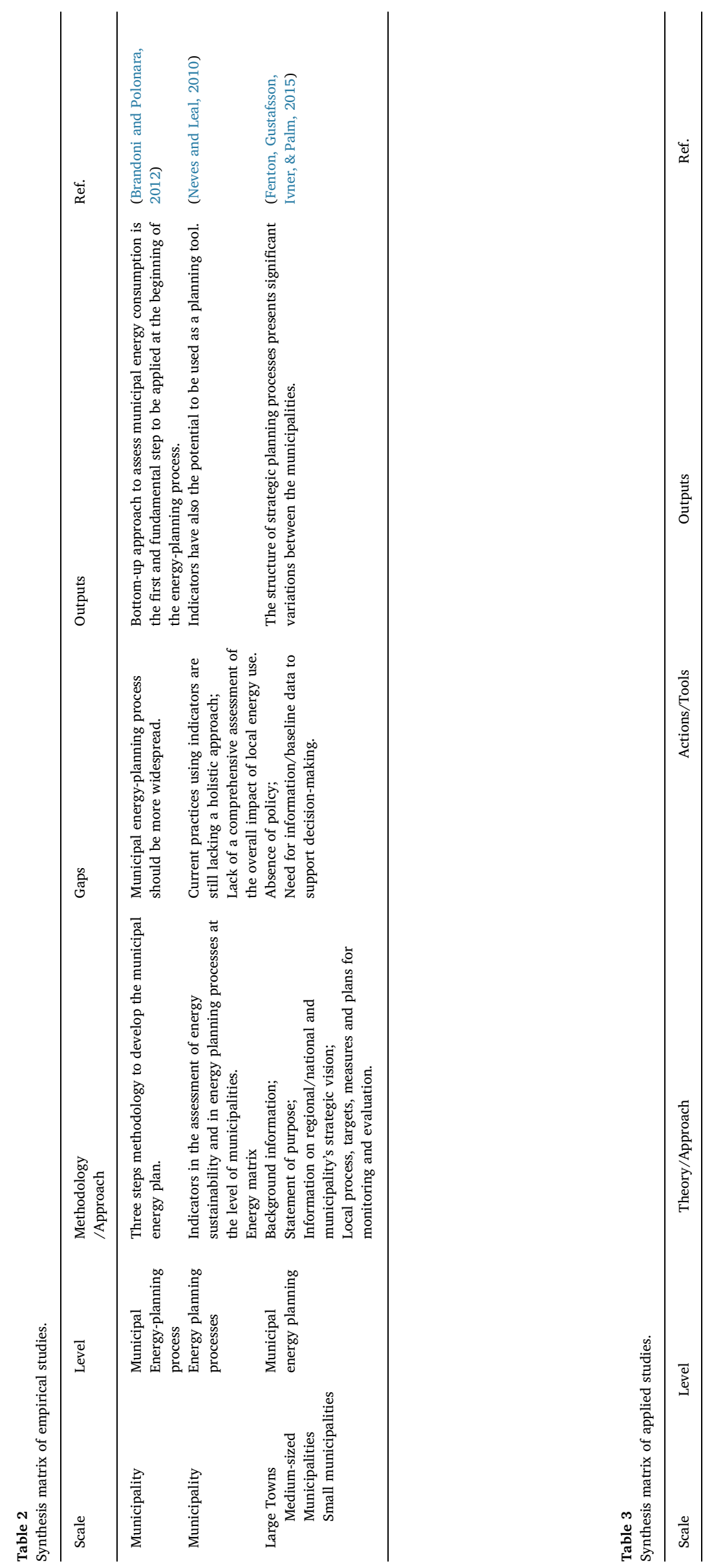

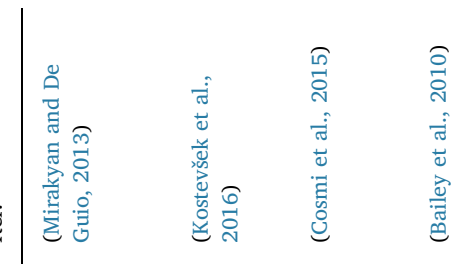

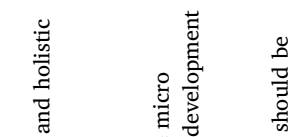

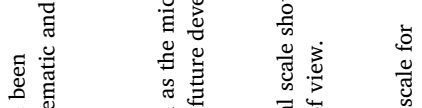

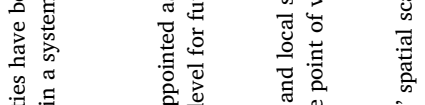

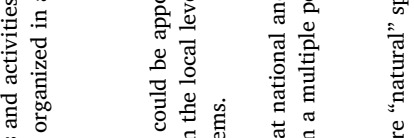

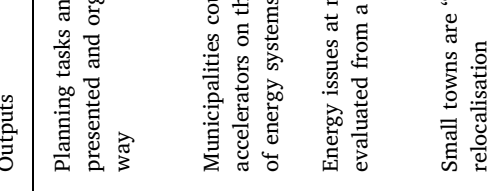

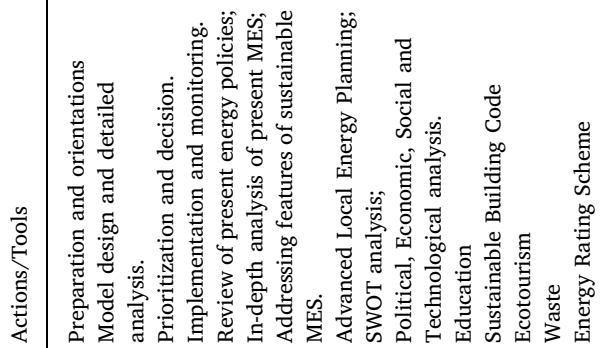

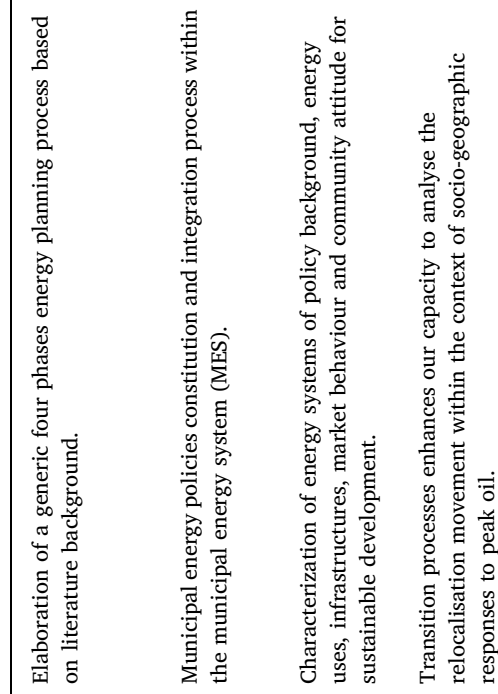

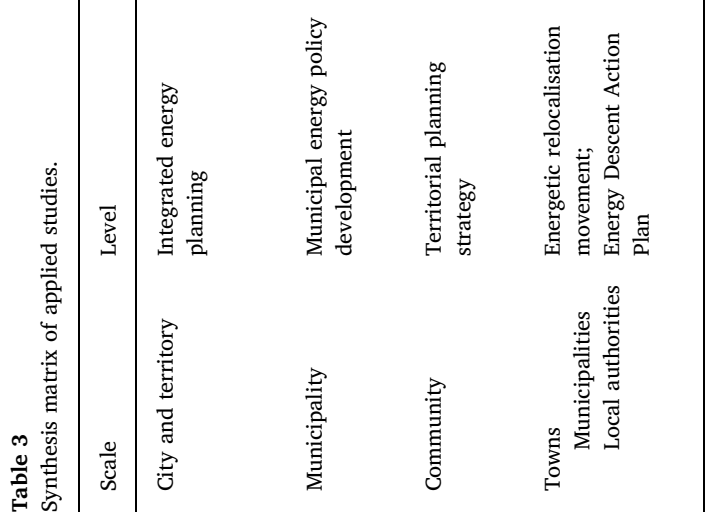


the selection of relevant research covered the following keywords: "local energy transition"; "municipal energy planning"; "energy efficiency in local planning"; "energy efficiency assessment municipal scale" and "energy efficient territories". Given the complex and interrelated natures of these issues; selected research has been divided into three categories.

1. Review studies that examine the comprehensive state of the art of energy efficiency and the local planning framework and highlight current knowledge gaps yet to be addressed (Table 1); 2. empirical studies that explain both the process and outcomes of existing methodologies and approaches already adopted or implemented by local governments (Table 2); and 3. applied studies that present new theories, approaches and tools, aimed at supporting or improving the current municipal energy planning process (Table 3 ).

This cross-disciplinary revision process led to the construction of the following three synthesis matrixes, which illustrate a range of energy efficiency and planning relationships, through a top-down analysis: city, city and territory, and municipality and community.

The first important evidence that emerges from the three matrixes is that the process of enhancing energy efficiency involves different scales and levels of intervention. Here local governments play the role of both stakeholders and policy makers in implementing the energy-saving initiatives (Rezessy, Dimitrov, Urge-Vorsatz, \& Baruch, 2006; Brandoni \& Polonara, 2012). Shifting from "government" to "governance", municipalities emerge as the micro accelerators on the local level for future development of energy systems (Kostevšek, Petek, Klemeš, \& Varbanov, 2016).

Indeed, review studies focused on the city scale confirm that energy efficiency improvements can be more effective if challenged by working across and beyond urban boundaries (Cajot et al., 2017). Despite the importance of such challenge, there are many studies that highlight the interrelated gaps and barriers but few provide empirical facts.

One example is that of Denmark, where energy saving at local scale is a focus area for which an institutional framework is under development or insufficient and for which local planning practices are incoherent (Sperling, Hvelplund, \& Mathiesen, 2011). Sperling et al. (2011) claim that, to achieve successful implementation of municipal energy plans, it is necessary to restructure the energy planning system.

A second example is Nilsson and Mårtensson's review, which documented the past and the present energy challenges in Sweden. Here, energy-planning has not been a prioritized subject in municipal plans, inducing vague goals and uncertainties (Nilsson \& Mårtensson, 2003). These examples have been chosen to introduce another alarming issue related to EU insights and guidelines that do not explicitly describe how energy and urban planning processes should be integrated (Cajot et al., 2017).

At this point, it is important to note that municipal energy planning has to deal with barriers whose nature seams operational. However, how should such planning be done? The translation of theories into practices, leading the way towards an energy-efficient municipality, is still emergent. There are, however, pioneering studies that are trying something new.

Cosmi et al. (2015) argue that self-assessment analysis is a basic step for the successful implementation of strategic energy policy and measures. The promotion of both renewable energy production and energy efficiency depends on the coordination of all the involved aspects and has to be supported by a comprehensive territorial planning strategy (Cosmi et al., 2015). Mirakyan and De Guio (2013) present an integrated energy planning procedure that is divided into four phases with several interlinked sub-activities and tasks (Mirakyan \& De Guio, 2013). Nevertheless, the lack of empirical and applied foundations of this study has led to the need and opportunity to develop more practiceoriented approaches to energy efficiency.

However, as Hopkins (2008) points out: "how this is explored and developed in practice will be different in each settlement: rather that offering perspective solutions, the Transition Movement aims to act as catalyst for a community to explore and come up with its own answers
(Hopkins, 2008: 88)". In this vein, the author provides an interesting "energy descent" (Hopkins, 2008:37) vision to promote social and political change, based on the concept of resilience and permaculture lessons (Bailey, Hopkins, \& Wilson, 2010). Hopkins's perspective emphasizes the need to start a comprehensive reduction in oil dependency through community-scale initiatives. Sustainable planning practices have been applied in Kinsale (Ireland) and Totnes (England). The experience of these projects provides insights towards a more holistic way of how local planning can articulate the energy descent process through various sectors, such as education, sustainable buildings, ecotourism, food, transport, waste, and energy rating scheme (Kinsale, 2005).

The recognition that current planning practices and tools do not contribute to enhancing energy efficiency at the municipal scale is a considerable gap that has to be addressed to yield new operative perspectives. In this context, the Municipal Masterplan (MMP) review emerges as an opportunity to implement actions in the field of energy efficiency. In line with the aforementioned framework, this paper tries to look at planning energy-efficient municipality. It does so by focusing on the first important step highlighted by Cosmi et al. (2015) and Mirakyan and De Guio (2013): the assessment of municipal energy performances.

This train of thought leads to the rediscovery of Geddes's "survey before plan", simultaneously conjuring up Hopkin's vision of local energy transition with the aim to projecting the insights of the past toward reliable practices in the future.

\section{Methodology}

Today, planning for energy efficient municipalities is not an end in itself, but rather a critical challenge to the elaboration of proposals capable of reducing energy consumption and introducing renewable energy sources at local scale. This consideration underlines the importance and opportunity of scientific studies applied to municipal planning process, focusing on the treatment of the energy efficiency in local development plans that have to be revised and replaced (Wilson, 2006).

In tackling these challenges, the present research recognises that increased energy efficiency forms part of different stages of defining and drawing up the municipal planning process. To this end, a comprehensive energy performance assessment of the whole municipal territory, capable of informing the following planning phases is developed. The case study method has been adopted to closely examine the data within a specific context: the municipality of Arraiolos in Portugal.

In this way, the assessment framework is concerned with four core dimensions of physical and functional municipal system: economic activity sectors, electricity distribution grids, the built environment and residential buildings. This clearly reflects a top-down approach that aims to analyse parameters, variables and indicators to assess energy performance at the municipal level. From a methodological point of view, the assessment process consists of five steps:

- Step 1 identifies economic activity sectors and provides a statistical analysis and quantitative information in terms of global electricity consumption patterns (Cosmi et al., 2015).

- Step 2 determines the spatial location of activity sectors with electricity consumption using Corine Land Cover. Here the traditional concept of zoning is associated with the concept of energy balance between the production from existent and future renewable energy plants and the demand from the electricity consumption cells, across the whole municipal territory. On this basis, local electricity distribution grids and electricity consumption zoning were overlapped to assess the spatial and functional coherence between territorial model and energy infrastructures.

- Step 3 focuses on the built environment with respect to the relationship between urban morphologies and bioclimatic factors.

- Step 4 considers the relationships between energy consumption, 
Table 4

Synthesis of the methodology for assessing energy efficiency.

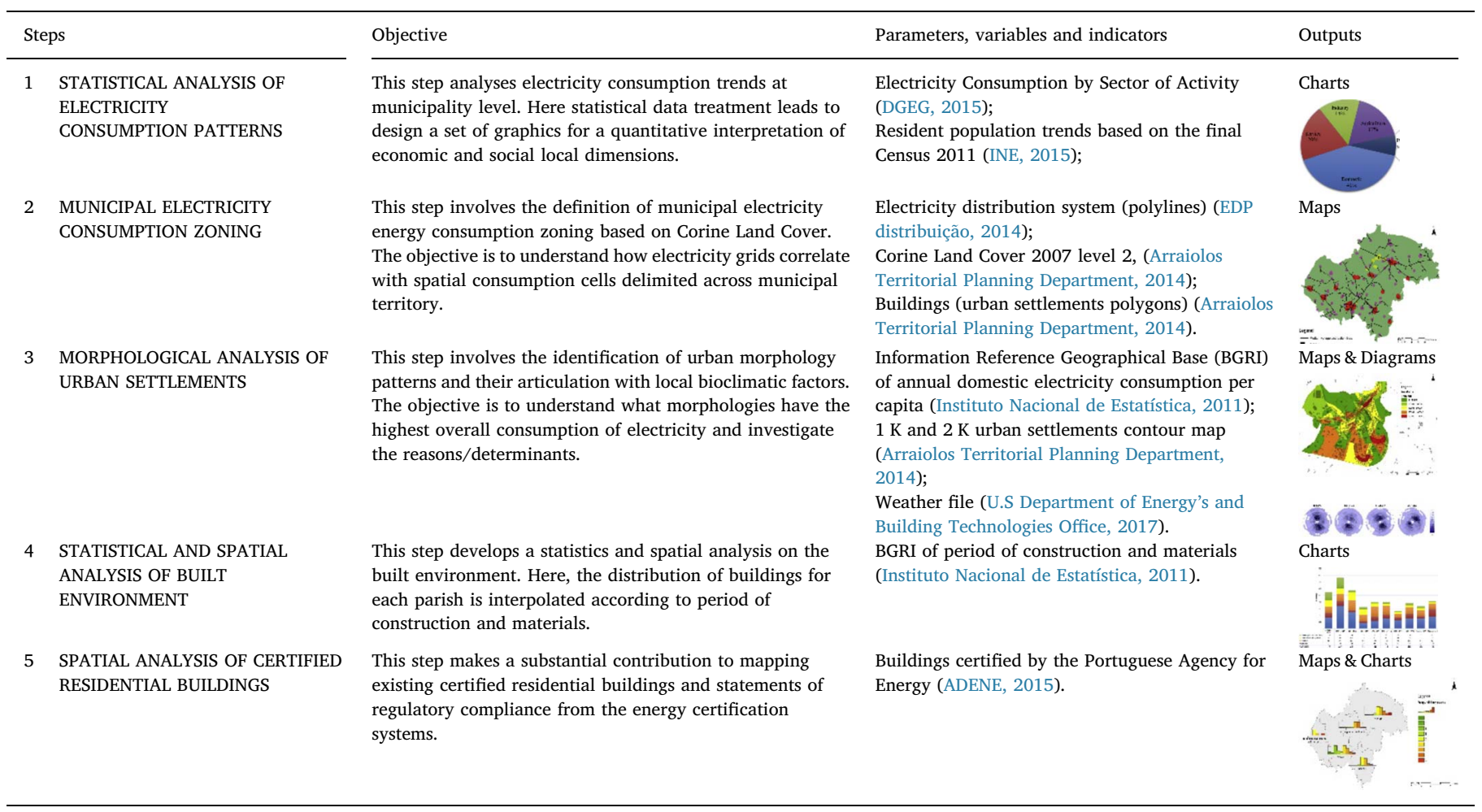

local construction systems and building materials.

- Step 5 provides a detailed analysis of energy efficiency classes of buildings, parish by parish, to assess, on average, the energy performance of the residential sector.

The following Table 4 table summarizes aforementioned steps, highlighting the objectives, data sources and outputs.

It is worth noting that this methodology integrates Geographical Information System to elaborate an energy efficiency-related database capable of connecting electricity energy consumption patterns with the multitude of parameters, variables and indicators expressed by the territory. As such, the approach promotes the analysis and correlation of top-down informative levels on energy and territory in a geographical manner.

\section{Case study}

This section presents a case study in Portugal to closely examine the practical application of the methodology within a specific context. Before moving to the energy-related issues, a brief introduction of the Portuguese planning system is given, followed by a description of the case study itself.

In Portugal, the system of planning currently in force is organized around a coordinated interacting framework relating to national, regional, intermunicipal and municipal levels and concerning the nature and territorial incidence of public interests involved (Lei no 31/2014 de 30 de Maio, 2014). Among these, of note is the importance of the Municipal Master Plan which has been shown to be one of the most effective territorial management instruments for the design, control and respective implementation of development at the local level (Fidélis, 2001). In this context, the revision phase of the MMP provides an opportunity and a need to draw up methodologies and implement actions promoting sustainable development. Indeed, this is why the first author has been involved in various MMP reviews, addressing a sustainable energy planning model to aid municipalities in planning for renewable energy in rural areas and enhancing energy efficiency at the municipal level (Amado, Poggi, \& Amado, 2016; Poggi et al., 2015).

As new models result from the transformation of existing ones, the development of a methodology associated with a case study was deemed the most appropriate approach to provide a contribution to knowledge in these fields.

Arraiolos is a predominantly rural municipality located in the Alentejo Region. It consists of seven parishes and has a surface area of approximately $693 \mathrm{~km}^{2}$ (Fig. 1).

The council created the MMP review in 2013. Here, one of the most predominate themes underlying the aspirations of local authorities was minimizing the use of energy by enhancing energy efficiency at municipal level.

From the outset, the assessment of the municipal energy performances involves understanding its relationship with the economic and social context, land use and cover, the configuration of infrastructures and the built environment.

By analysing energy consumption indicators per energy source, it can be seen that electricity is the main source of energy used in the Arraiolos Municipality. In this context, the graph in Fig. 2 shows the development of electricity consumption as related to the demographic dynamics verified in the Arraiolos Municipality between 1994 and 2012.

It is possible to see how the increase in electricity consumption between 1994 and 2007 corresponded to a reduction in the resident population, a fact which can be explained through the considerable impact due to the increase in the demand for thermal comfort and the growth in the number of electrical devices placed in homes (Inquérito ao Consumo de Energia no Sector, 2011). However, a reversal in the upward trend in electricity consumption can be seen from 2010 onwards, reflecting, on the one hand, the consequences of the 2008 economic crisis and the 2009 economic recession and, on the other, the effects of the entry into force of energy efficiency measures as laid down by the Energy Efficiency Action Plan 2008-2015.

The weighting of electricity consumption in the energy balance of 


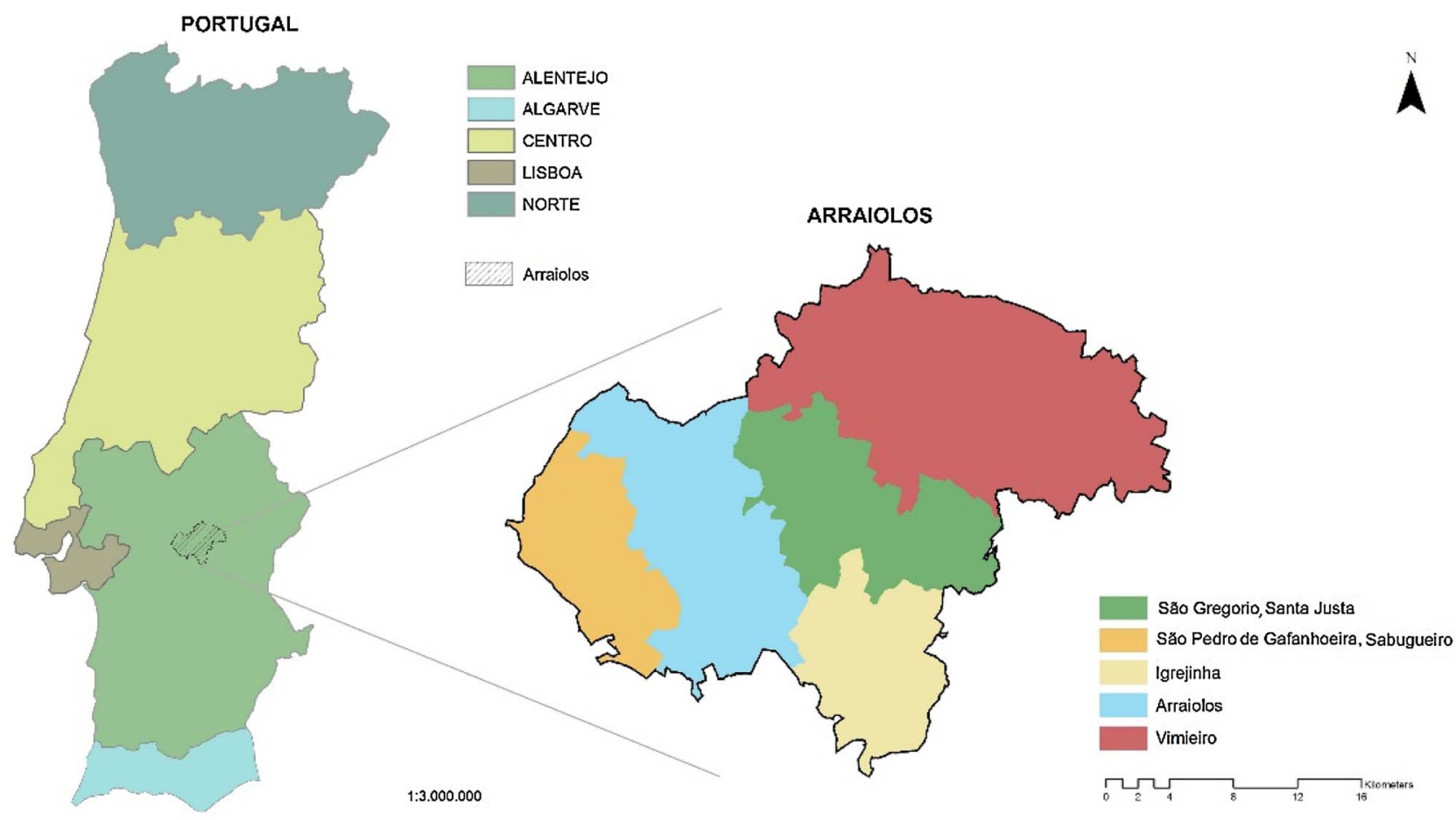

Fig. 1. Arraiolos Municipality location and parish boundary reference map.

the municipality is demonstrative of the gradual increase in energy demand in the main activity sectors, particularly domestic, trade and services, agriculture, industry, and in the public sectors, such as roads and state buildings lighting (Fig. 3).

Fig. 3 highlights the high electricity consumption of the domestic sector, taking up around $41 \%$ of the total electricity used in the municipality. The non-domestic sector, included in the Portuguese Classification of Economic Activities, 3rd Rev, shows a highly significant share of consumption (20\%), followed by the agricultural sector, which represents $17 \%$. Among the different sectors of activity present in the urban settlements, electricity consumption in residential, trade and public administration buildings constitutes an important reference in understanding the interactions characterising the energy performance of a municipality. The incidence of these sectors of activity can be translated into a spatial model associated with the transportation, distribution and use of electricity (Fig. 4).

Electricity consumption cells result from the delimitation of the continuous urban fabric, concentrated in 11 urban settlements, and scattered economic activities in rural areas. The spatial configuration of

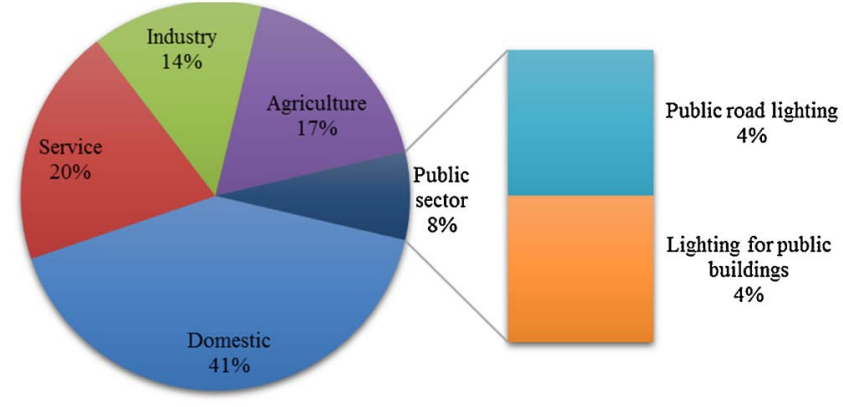

Fig. 3. Electricity consumption by sector of activity in 2012 .

the electricity distribution grid in relation to such consumption cells, reveals a model valuable to both urban planners and electricity operators. It should be noted that the electricity distribution grid presents a reticular network topology that has to be assessed considering the implementation of future renewable electricity power systems (Morvaj,

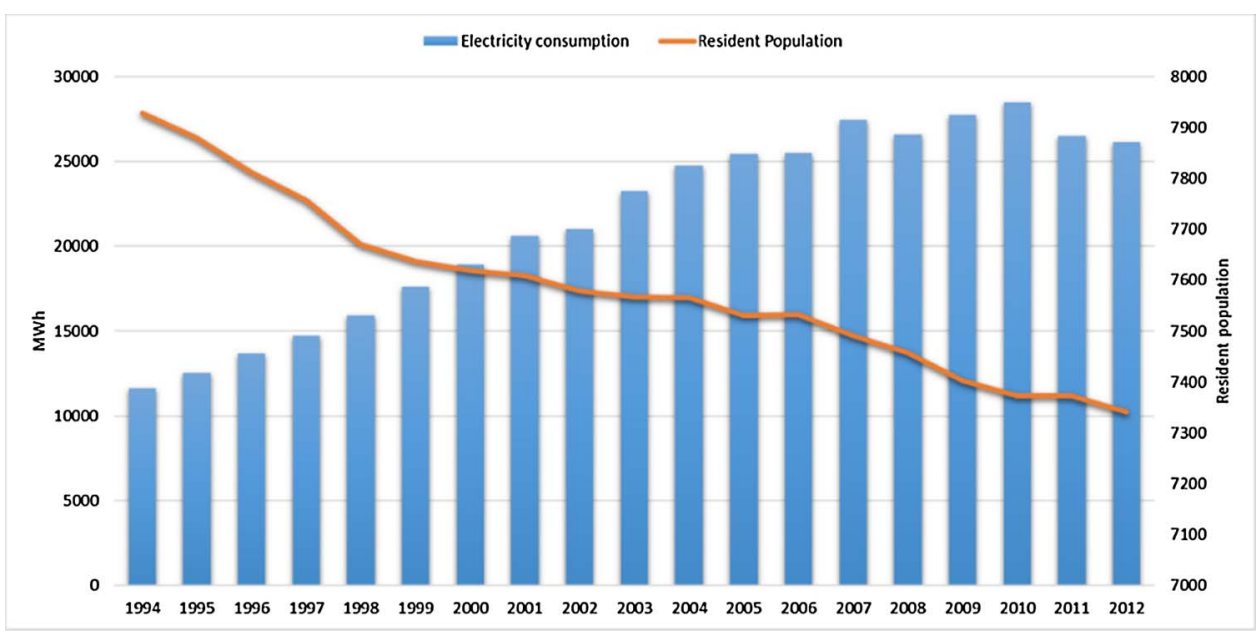

Fig. 2. Electricity consumption trend in relation to the resident population in the Arraiolos Municipality. 


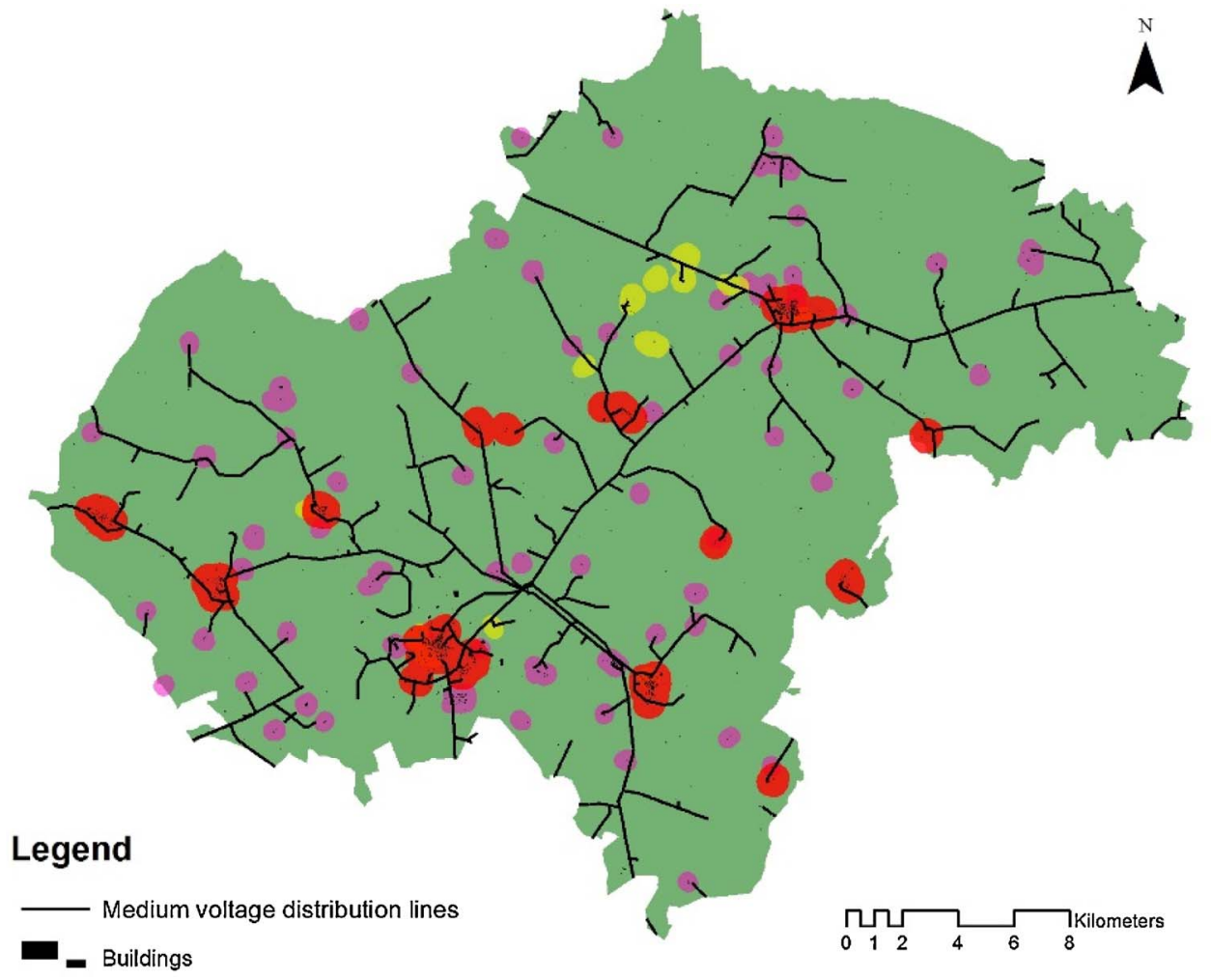

Corine Land Cover 2007 level 2

\section{Electricity consumption cells}

Urban fabric

Mine, dump and construction sites

Industrial, commercial and transport

\section{Net-Zero electricity demand areas}

Artificial non-agricultural vegetated

Permanent crops Forests

Heterogeneous agricultural areas

Open spaces with little or no vegetation

Shrubs and/or herbaceous vegetation

Arable land Pastures Inland waters
Fig. 4. Spatial configuration of medium voltage distribution grid in relation to electricity energy consumption cells.
Evins, \& Carmeliet, 2017), and the integration of smart technologies in the conventional grid (Colak, Kabalci, Fulli, \& Lazarou, 2015).

Due to the high demand for electricity in the domestic sector and its weight in the overall energy balance of the municipality, an in-depth analysis of urban settlements plays a key role in assessing the energy efficiency.

As such, the annual domestic electricity consumption per capita, which in Arraiolos is $1460 \mathrm{kWh}$ (INE, 2015), is correlated with the number of inhabitant of each statistical subsection. $1 \mathrm{~K}$ and $2 \mathrm{~K}$ contour maps supplied by the territorial planning department were used to explore the relationships between urban morphology and residential energy consumption, as suggested by Ratti, Baker, and Steemers (2005) (Fig. 5).

From the study shown in Fig. 5, it is possible to identify urban morphologies which have the worst performance overall (Fig. 6). They are located along the organic linear road patterns and are characterised by small-sized buildings, with 1-2 floors throughout the municipality, with an occasional maximum of 3-4 floors in the main urban area of Arraiolos.

Here, it is important to reflect on local bioclimatic variables as well as the incidence of the construction periods of buildings and the respective construction systems and materials in terms of energy efficiency.

The location of the Arraiolos Municipality in a I1-V3 climate zone strongly influences the consumption of energy in the buildings to satisfy cooling needs in the summer and ensure thermal comfort during the 5.7 month heating season in winter (Decree-Law No. 80/2006). Furthermore, it is worth highlighting that the orientation of existing buildings, due to their exposure to the sun, influences their energy efficiency, naturally favouring better thermal performance in the winter, but increasing the indoor temperature in the summer.

In this regard, Fig. 7 shows the best theoretical building orientation simulated by Ecotect Weather Tool. ${ }^{1}$ By comparing this reference diagram with Fig. 6, it is possible to understand that the current orientation of urban morphologies may be one of the determinant factors of highest overall electricity consumption.

On the other side, local wind direction and frequency prevail from N-NNE and S-SSW during the Spring and the Autumn seasons, from NNW in the summer and SE-NW in the Winter (Fig. 8). Here it is important to observe the direct link between urban morphologies and natural ventilation of buildings, which, due to local annual wind variation, can determinate impacts in terms of energy requirement for heating and cooling.

Moving the assessment down to the scale of the built environment, residential buildings emerge as a connecting thread between the local

\footnotetext{
${ }^{1}$ The Evora weather file was used for the simulations (Lei no 31/2014 de 30 de Maio, 2014). It should be noted that Evora is located approximately $25 \mathrm{~km}$ south of the Arraiolos municipality. Such minimal difference in latitude between Arraiolos and Evora can be considered as not influential in terms of the solar path.
} 


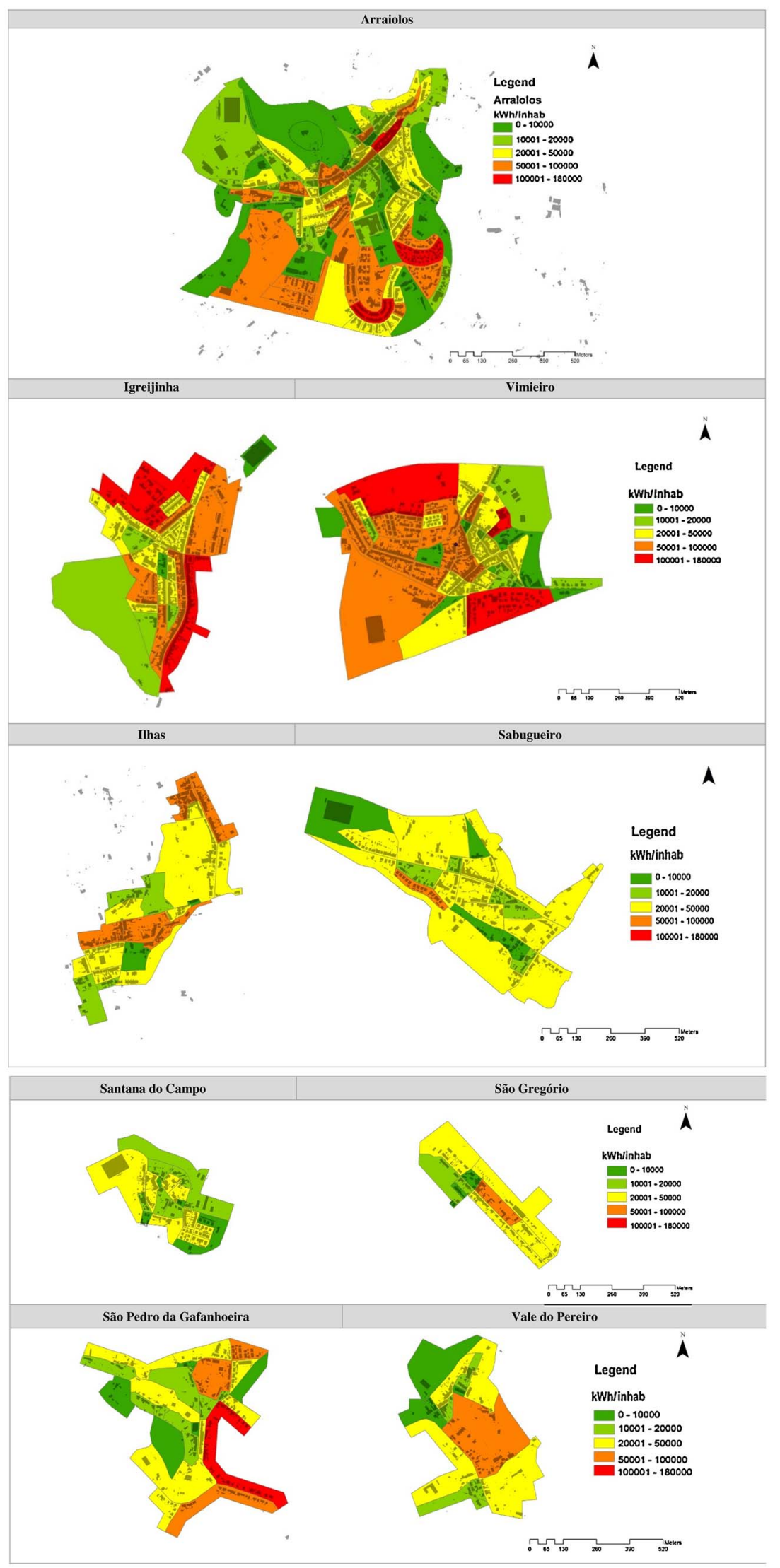

Fig. 5. Annual domestic electricity consumption per capita in the main urban settlements of the municipality (kWh/inhab). 


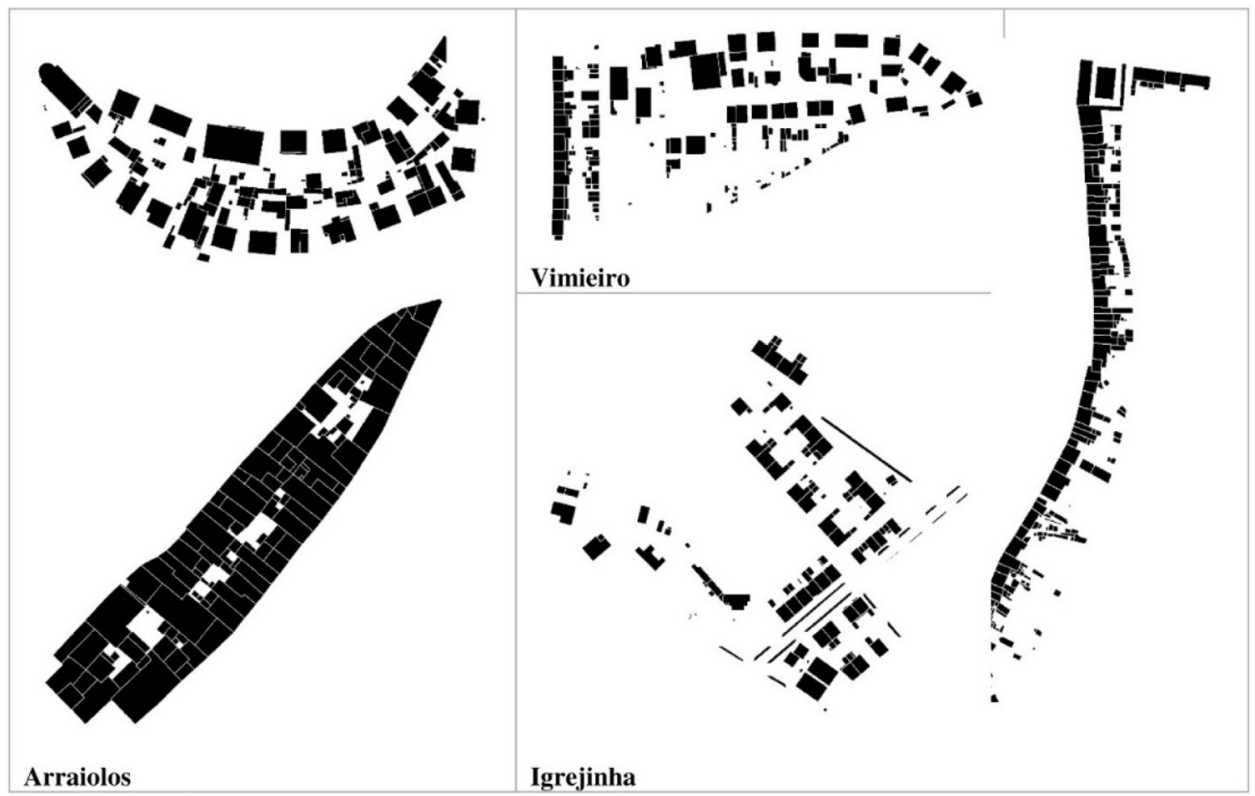

Fig. 6. Urban morphologies that have the highest overall consumption of electricity.

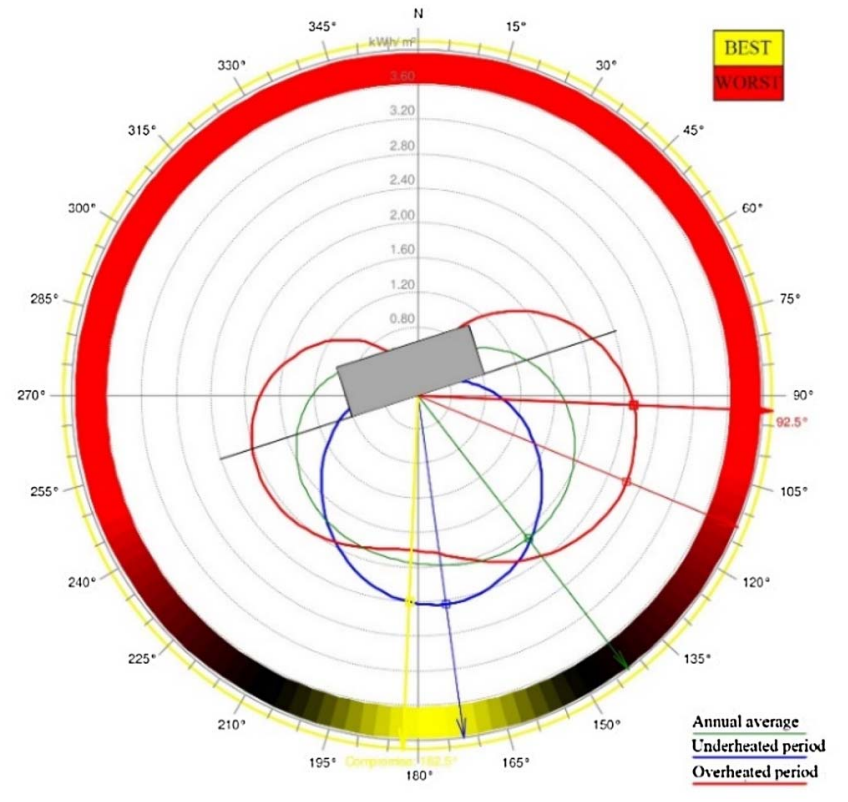

Fig. 7. Diagram of the best theoretical building orientation.

and global scale of municipal energy performances. Indeed, the residential sector is the largest energy consumer (see Fig. 3) and one of the main field of local planning action. Moreover, the energy performances of residential buildings affect the local population's well-being and health. As such, they are a focal point of this assessment process.

In this framework, it is worth highlighting that the period of construction of buildings is an important energy performances indicator (Csoknyai et al., 2016).

Fig. 9 shows how the buildings constructed before the 1960s play a dominant role in all parishes given that this situation negatively influences the overall energy performance in the existing construction within the municipality.

Buildings with plate $^{2}$ structure form the highest percentage of buildings in the municipality, coinciding in large part with the

\footnotetext{
${ }^{2}$ The plate structure adopts masonry as the main structural material, but with a small slab of reinforced concrete on the rear of the building.
}

buildings constructed in the period between 1919 and 1945 (Fig. 10).

What is more, the parish of Vimieiro has buildings from more recent periods mainly with concrete structures, whereas the masonry and stone/adobe structures are distributed in a uniform manner among all the parishes of the municipality without being significant in terms of the number of buildings.

By analysing the building structure, it is possible to state that the masonry have the worst energy performance due to their low thermal inertia and the existence of thermal bridges in the constructed envelope, their lack of insulation and the presence of windows with metal frames and single glazing.

The buildings with the stone/adobe structure ensure a better indoor level of comfort due to the greater thermal inertia of their walls; however, it should be mentioned that the overall performance result is lowered by the type of windows, with wooden or metal frames and single glazing.

The buildings with a masonry structure and reinforced concrete, built in more recent periods, reflect improved energy performance resulting from the introduction of new rules to the design and construction laid down by the Regulations on Characteristics of the Thermal Behaviour of Buildings (RCCTE), which have been in force since mid2006.

As an example, Fig. 11 shows the evolution of building typologies in the municipality, according to the variation in their respective energy performance level.

Considering the major impact of residential buildings on municipal energy performance, we decided to strengthen this assessment process by mapping the buildings certified by the Portuguese Agency for Energy (Agencia para a Energia - ADENE). To carry out this study, data were used from the ADENE online platform referring to March 2015 (ADENE, 2015). The map of Fig. 12 permits us to analyse the spatial distribution of the certified buildings and their respective energy class as recorded in the Arraiolos parishes.

According to the legislation in force in the National System for Energy Certification for Buildings, such information is characterised as the performance evaluation of the buildings, on a scale of 9 classes from class A+ (the most efficient) to $\mathrm{G}$ (least efficient). Table 5 below shows with greater detail that approximately $65 \%$ of the certified residential buildings have energy classes between $\mathrm{C}$ and $\mathrm{E}$ and that the set of buildings with classes above B are only recorded in the parish of Arraiolos. 


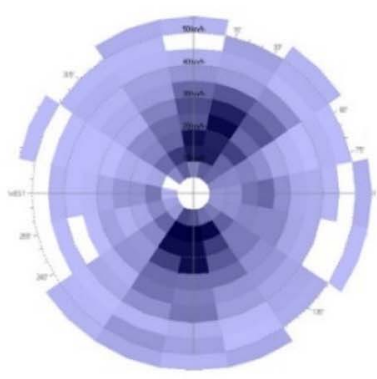

SPRING

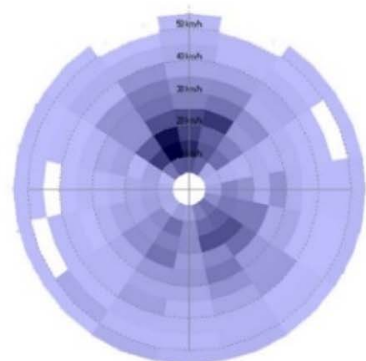

SUMMER

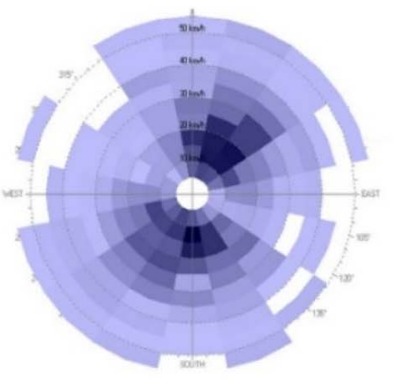

AUTUMN

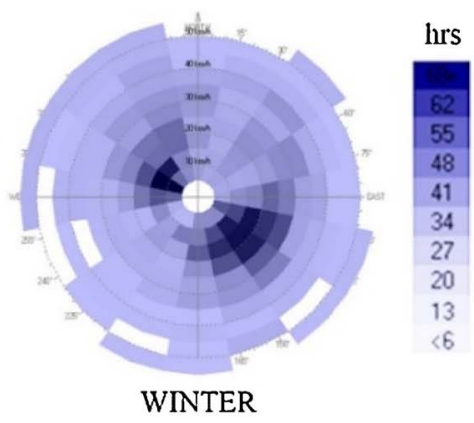

Fig. 9. Distribution by parish of the number of buildings according to period of construction.
Fig. 10. Distribution by parish of the number of buildings according to structure.

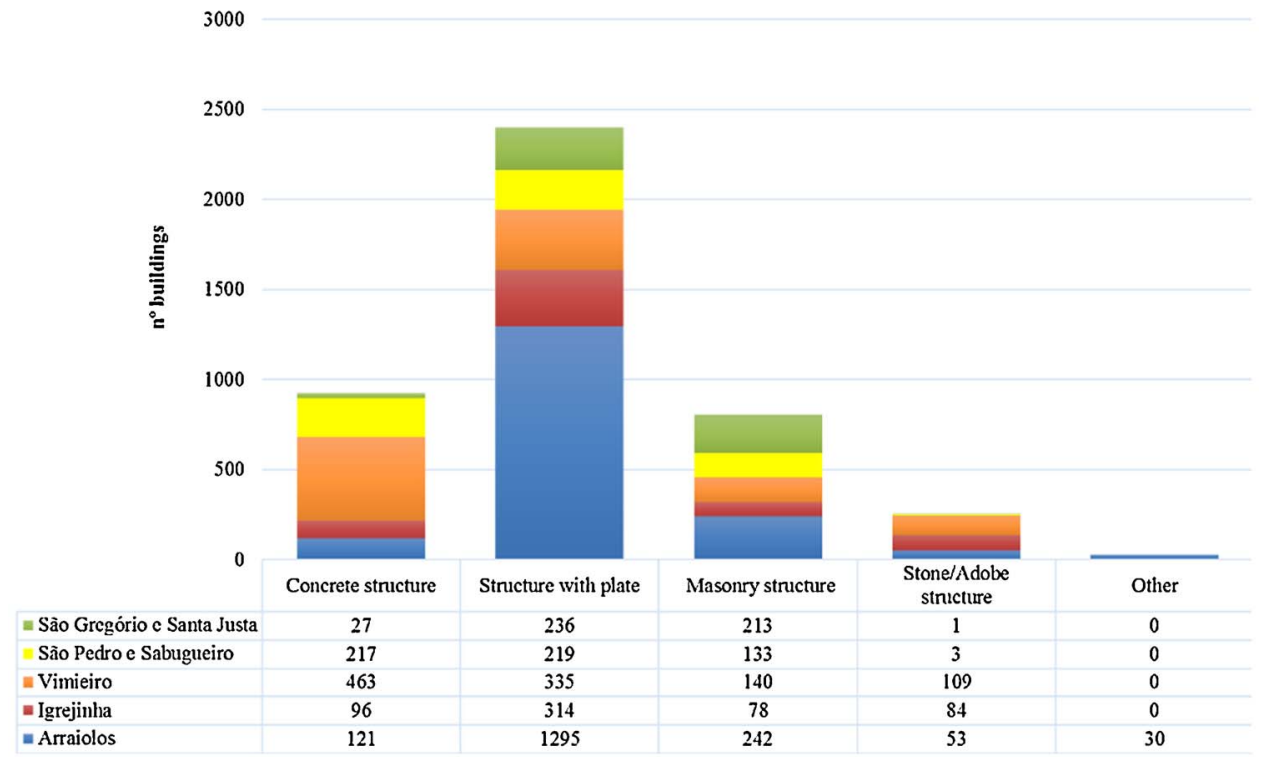

\section{Discussion and conclusions}

According to European Union climate and energy policies, regional and local governments are encouraged to adopt energy efficiency plans that contain specific energy saving and efficiency objectives and actions. Nevertheless, the literature review highlights a considerable gap in the elaboration of practice-oriented approaches capable of aiding local authorities in the preparation of development plans where energy efficiency goals are covered. The limited number of empirical and applied studies evidences a lack of a linear municipal energy planning process, in which a sequence of steps is taken from problem formulation through analysis, diagnostic and implementation to evaluation and feedback.

The results of this research refer to a comprehensive assessment of 


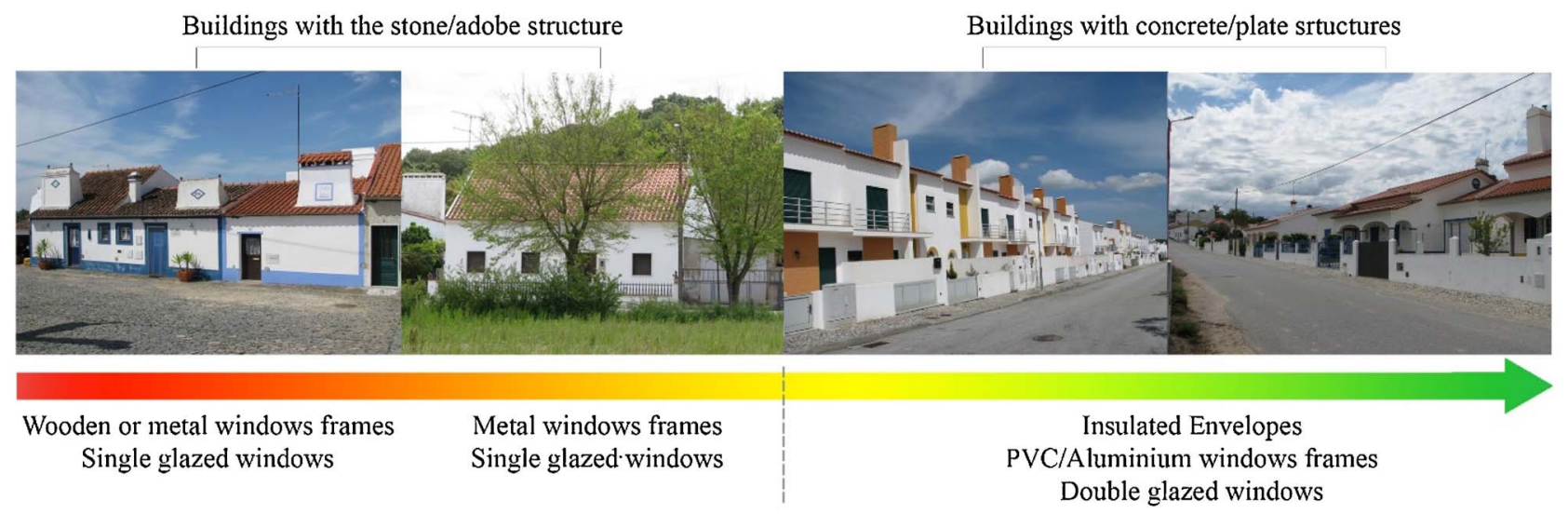

Fig. 11. Evolution of the different typologies of buildings in the municipality and their respective energy performance level.

parameters, variables and indicators associated with municipal energy performance.

From the correlation between statistical energy consumption patterns and the spatial incidence of economic activity sectors, it was possible to identify electricity consumption cells that permit the planning of functional allocation of economic activities on the basis of a potential balance between energy demand and production poles. It is at this level that the modernization of the electricity system, through smart technologies, can provide local planners with meter information to manage energy balance within municipal boundaries. Here, energy performances-informed land use zoning can enhance energy efficiency by interconnecting higher density areas with more compact and mixed uses with a surplus of on-site generation to share. New scenarios, will also characterize electricity grid expansion, considering topological optimization within new and existing urban areas to improve energy efficiency.

The study of urban morphology provides insights into various planning and design domains: how do patterns repeat themselves at different spatial scales, what physical parameters characterize historic and oldest areas in different settlements, how does the built environment shape and how do dimensions influence thermal comfort conditions in public space. Indeed, the analysis of urban morphologies and local bioclimatic conditions represents a powerful tool for the determination of the fundamental parameters that local planning has to follow to achieve settlements with better energy performances. Here, local planning coupled with urban design, plays a key role in relating bioclimatic concepts with the layouts of streets and public spaces, the dimension and form of the lots, the orientation and volume of buildings, and so on, creating energy-efficient urban morphologies.

"From urban settlement to built environment", residential buildings emerge as a core field for local planning intervention promoting energy efficiency. As a matter of fact, the construction and retrofitting of buildings is regulated by the local administration through its municipal code and land use standards. The period of construction allows a relationship to form between the building structure, the materials and thermal insulation systems used in the buildings. It should be added that these factors strongly interfere with indoor levels of thermal comfort and, consequently, with the energy performance of a building. Indeed, these considerations have important implications for energy policy design. An example is the case of residential buildings that can be classified according to the period of construction:

i. . buildings that are part of the historic and monumental heritage; ii. . buildings constructed in the 50's, 60's and 70's;

iii. . buildings constructed in the 80's and 90's;

iv. . buildings constructed after the 00's.

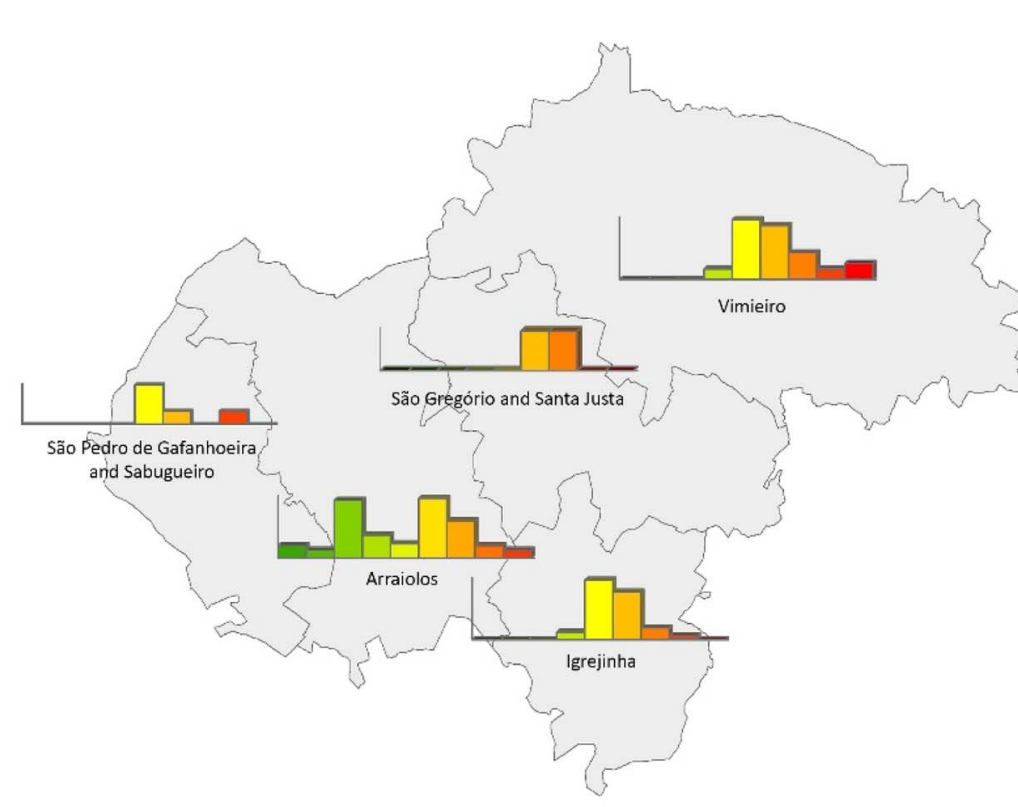

\section{Legend}

Energy efficiency classes

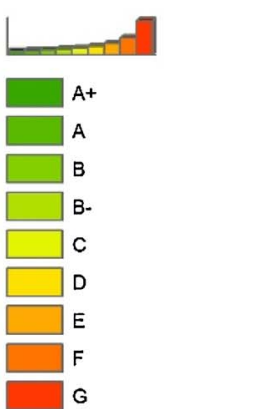

Fig. 12. Map of certified buildings and respective energy efficiency class per parish. 
Table 5

no. of buildings and respective energy classes per parish.

\begin{tabular}{|c|c|c|c|c|c|c|c|c|c|c|}
\hline & $\mathrm{A}+$ & A & B & B- & $\mathrm{C}$ & $\mathrm{D}$ & $\mathrm{E}$ & $\mathrm{F}$ & G & \\
\hline São Gregório and Santa Justa parishes & - & - & - & - & - & 1 & 1 & - & - & \\
\hline São Pedro de Gafanhoeira and Sabugueiro parishes & - & - & - & - & 3 & 1 & - & - & 1 & $\mathrm{~A}+$ \\
\hline Vimieiro & - & - & - & 2 & 11 & 10 & 5 & 2 & 3 & \\
\hline Igrejinha & - & - & - & 2 & 15 & 12 & 3 & 1 & - & A \\
\hline Arraiolos & 6 & 4 & 28 & 11 & 7 & 29 & 18 & 6 & 4 & $\mathrm{~B}$ \\
\hline Total & 4 & 4 & 28 & 15 & 36 & 53 & 27 & 9 & 8 & B- \\
\hline
\end{tabular}

Such a classification, developed in GIS environment, can provide significant contributions as a decision-making tool in supporting rehabilitation, regeneration and retrofitting programmes that can be organized at the neighborhood level by adopting specific energy savings measures.

The municipal energy performances assessment presented in this paper aims to provide the basis for setting fields of interventions and priorities. From this top-down approach, it is possible understand that energy efficiency is a cross-cutting issue interrelated to a blend of various disciplines: geography, spatial planning, urbanism, architecture, and civil engineering. The discussion of results enables us to understand why municipalities should be called upon to enhance energy efficiency by first looking at a comprehensive energy performance assessment. Embracing the whole municipal territory rather than only urban areas is key to articulating energy efficiency and geographical, social, environmental and economic factors, which are at the core of local planning. Tackling these issues, the developed methodology may be a valuable contribution especially within the MMP revision process, given that the former incorporates energy concerns and adjusts them to the current challenges for sustainable development. It is here that municipalities, through their local plan, must take the lead addressing a comprehensive "energy descent" vision.

\section{Acknowledgements}

The first author thanks the Portuguese Fundação para a Ciência e Tecnologia (FCT) for the financial support through the PhD Fellowship SFRH/BD/94702/2013

\section{References}

ADENE (2015). Edifícios certificados. [http://www.adene.pt/sce/micro/certificados-energeticos].

Abdelaziz, E. A., Saidur, R., \& Mekhilef, S. (2011). A review on energy saving strategies in industrial sector. Renewable and Sustainable Energy Reviews. 15, 150-168. http://dx. doi.org/10.1016/j.rser.2010.09.003.

Afgan, N. H., Gobaisi, D. A., Carvalho, M. G., \& Cumo, M. (1998). Sustainable energy development. Renewable and Sustainable Energy Reviews, 2, 235-286. http://dx.doi. org/10.1016/S1364-0321(98)00002-1.

Amado, M., Poggi, F., \& Amado, A. R. (2016). Energy efficient city: a model for urban planning. Sustainable Cities and Society, 26, 476-485. http://dx.doi.org/10.1016/j. scs.2016.04.011.

Arraiolos Territorial Planning Department (2014). 1 k and $2 \mathrm{~K}$ contour map. [http:// sig.municipioarraiolos.pt/ Accessed 1 April 2013].

Atzori, L., Iera, A., \& Morabito, G. (2016). Understanding the Internet of Things: definition, potentials, and societal role of a fast evolving paradigm. Ad Hoc Networks. http://dx.doi.org/10.1016/j.adhoc.2016.12.004.

Bailey, I., Hopkins, R., \& Wilson, G. (2010). Some things old, some things new: the spatial representations and politics of change of the peak oil relocalisation movement. Geoforum, 41, 595-605. http://dx.doi.org/10.1016/j.geoforum.2009.08.007.

Battarra, R., Gargiulo, C., Pappalardo, G., Boiano, D. A., \& Oliva, J. S. (2016). Planning in the era of Information and Communication Technologies. Discussing the label: smart in South-European cities with environmental and socio-economic challenges. Cities,
59, 1-7. http://dx.doi.org/10.1016/j.cities.2016.05.007.

Boyle, G. (2012). Renewable energy: power for a sustainable future, 3.

Brandoni, C., \& Polonara, F. (2012). The role of municipal energy planning in the regional energy-planning process. Energy, 48, 323-338.

Bulkeley, H., \& Betsill, M. (2005). Rethinking sustainable cities: multilevel governance and the urban politics of climate change. Environmental Politics, 14, 42-63. http://dx. doi.org/10.1080/0964401042000310178.

Cajot, S., Peter, M., Bahu, J.-M., Guignet, F., Koch, A., \& Maréchal, F. (2017). Obstacles in energy planning at the urban scale. Sustainable Cities and Society. http://dx.doi.org/ 10.1016/j.scs.2017.02.003.

Calvillo, C. F., Sánchez-Miralles, A., \& Villar, J. (2016). Energy management and planning in smart cities. Renewable and Sustainable Energy Reviews, 55, 273-287. http://dx.doi. org/10.1016/j.rser.2015.10.133.

Clack, B., \& York, R. (2005). Carbon metabolism: global capitalism, climate change, and the biospheric rift. Theory and Society, 34, 391-428.

Colak, I., Kabalci, E., Fulli, G., \& Lazarou, S. (2015). A survey on the contributions of power electronics to smart grid systems. Renewable and Sustainable Energy Reviews, 47, 562-579. http://dx.doi.org/10.1016/j.rser.2015.03.031.

Cosmi, C., Dvarionienè, J., Marques, I., Di Leo, S., Gecevičius, G., Gurauskienė, I., et al. (2015). A holistic approach to sustainable energy development at regional level: the RENERGY self-assessment methodology. Renewable and Sustainable Energy Reviews, 49, 693-707. http://dx.doi.org/10.1016/j.rser.2015.04.094.

Csoknyai, T., Hrabovszky-Horváth, S., Georgiev, Z., Jovanovic-Popovic, M., Stankovic, B., Villatoro, O., et al. (2016). Building stock characteristics and energy performance of residential buildings in Eastern-European countries. Energy and Buildings, 132, 39-52. http://dx.doi.org/10.1016/j.enbuild.2016.06.062.

DGEG (2015). Energia eléctrica - consumos por concelho - por sector de actividade. [http:// www.dgeg.pt/ Accessed 15 April 2015].

Decreto-Lei no, 2017 80/2006 de 4 de Abril, Regulamento das Características de Comportamento Térmico dos Edifícios, n.d.

U.S. Department of Energy's and Building Technologies Office, PRT_Evora.085570, n.d https://energyplus.net/weather-location/europe_wmo_region_6/PRT/PRT_Evora. 085570_IWEC [Accessed 20 January 2017].

Fenton, P., Gustafsson, S., Ivner, J., \& Palm, J. (2015). Sustainable Energy and Climate Strategies: lessons from planning processes in five municipalities. Journal of Cleaner Production, 98, 213-221. http://dx.doi.org/10.1016/j.jclepro.2014.08.001.

Fidélis, T. (2001). Planeamento territorial e ambiente: o caso da envolvente à Ria de Aveiro. Cascais: Principia.

García-Álvarez, M. T., Moreno, B., \& Soares, I. (2016). Analyzing the sustainable energy development in the EU-15 by an aggregated synthetic index. Ecological Indicators, 60 , 996-1007. http://dx.doi.org/10.1016/j.ecolind.2015.07.006.

Geddes, P. (1915). Cities in evolution: an introduction to the town planning movement and to the study of civics. London: WILLIAMS \& NORGATE.

Gellings, C. W. (2009). Efficient use and conservation of energy. Oxford: EOLSS Publications.

Goldman, T., \& Gorham, R. (2006). Sustainable urban transport: four innovative directions. Technology in Society, 28, 261-273. http://dx.doi.org/10.1016/j.techsoc. 2005. 10.007.

Hopkins, R. (2008). The transition handbook: from oil dependency to local resilience, $1^{\circ}$. Cambridge: Green Books.

INE (2015). Estatísticas territoriais. [http://www.ine.pt/xportal/xmain?xpid = INE $\&$ xpgid $=$ ine_unid_territorial $\&$ menuBOUI $=13707095 \&$ contexto $=$ ut \& selTab $=$ tab3 Accessed 13 April 2015].

Inquérito ao Consumo de Energia no Sector, I. N. E. (2011). Doméstico lisboa DGEG.

Instituto Nacional de Estatística (2011). Information reference geographical base (BGRI) [http://www.ine.pt/xportal/xmain?xpid = INE \& xpgid = ine_main Accessed 4 September 2014].

Jia, M., Srinivasan, R. S., \& Raheem, A. A. (2017). From occupancy to occupant behavior: an analytical survey of data acquisition technologies, modeling methodologies and simulation coupling mechanisms for building energy efficiency. Renewable and Sustainable Energy Reviews, 68(Part 1), 525-540. http://dx.doi.org/10.1016/j.rser. 2016.10.011.

Karan, E., Mohammadpour, A., \& Asadi, S. (2016). Integrating building and 
transportation energy use to design a comprehensive greenhouse gas mitigation strategy. Applied Energy, 165, 234-243. http://dx.doi.org/10.1016/j.apenergy.2015. 11.035.

Kinsale, F. E. C. (2005). An energy descent action plan. 2005.

Kolokotsa, D., Rovas, D., Kosmatopoulos, E., \& Kalaitzakis, K. (2011). A roadmap towards intelligent net zero- and positive-energy buildings. Solar Energy, 85, 3067-3084.

Kostevšek, A., Petek, J., Klemeš, J. J., \& Varbanov, P. (2016). Municipal energy policy constitution and integration process to establish sustainable energy systems-a case of the Slovenian municipality. Journal of Cleaner Production, 120, 31-42. http://dx. doi.org/10.1016/j.jclepro.2016.01.046.

R. Laughlin, Powering the Future: How We Will (eventually) Solve the Energy Crisis and Fuel the Civilization of Tomorrow, $1^{\circ}$, Basic, New York, 2012.

Lei no 31/2014 de 30 de Maio (2014). Lei de bases gerais da política pública de solos, de ordenamento do território e de urbanismo.

Li, T., Baležentis, T., Makutėnienè, D., Streimikiene, D., \& Kriščiukaitienė, I. (2016) Energy-related $\mathrm{CO} 2$ emission in European Union agriculture: driving forces and possibilities for reduction. Applied Energy, 180, 682-694. http://dx.doi.org/10.1016/ j.apenergy.2016.08.031.

Mirakyan, A., \& De Guio, R. (2013). Integrated energy planning in cities and territories: a review of methods and tools. Renewable and Sustainable Energy Reviews, 22, 289-297. http://dx.doi.org/10.1016/j.rser.2013.01.033.

Morvaj, B., Evins, R., \& Carmeliet, J. (2017). Decarbonizing the electricity grid: the impact on urban energy systems, distribution grids and district heating potential. Applied Energy, 191, 125-140. http://dx.doi.org/10.1016/j.apenergy.2017.01.058.

Neves, A. R., \& Leal, V. (2010). Energy sustainability indicators for local energy planning: review of current practices and derivation of a new framework. Renewable and Sustainable Energy Reviews, 14, 2723-2735. http://dx.doi.org/10.1016/j.rser.2010. 07.067.

Nilsson, J. S., \& Mårtensson, A. (2003). Municipal energy-planning and development of local energy-systems. Applied Energy, 76, 179-187. http://dx.doi.org/10.1016/ S0306-2619(03)00062-X.

Pasimeni, M. R., Petrosillo, I., Aretano, R., Semeraro, T., De Marco, A., Zaccarelli, N., et al. (2014). Scales, strategies and actions for effective energy planning: a review. Energy Policy, 65, 165-174.

Poggi, F., Firmino, A., \& Amado, M. (2015). Moving forward on sustainable energy transitions: the smart rural model. European Journal of Sustainable Development, 4 43-50. http://dx.doi.org/10.14207/ejsd.2015 [v4n2p43].

Ratti, C., Baker, N., \& Steemers, K. (2005). Energy consumption and urban texture. Energy and Buildings, 37, 762-776.

Rezessy, S., Dimitrov, K., Urge-Vorsatz, D., \& Baruch, S. (2006). Municipalities and energy efficiency in countries in transition: review of factors that determine municipal involvement in the markets for energy services and energy efficient equipment, or how to augment the role of municipalities as market players. Energy Policy, 34, 223-237. http://dx.doi.org/10.1016/j.enpol.2004.08.030.

Rosa, F., \& Neves, P. (2010). Eficiência Energética e Ordenamento do Território. Contributo DGOTDU Para O Barómetro Da Eficiência Energética Portugal, 2011.

Ruparathna, R., Hewage, K., \& Sadiq, R. (2016). Improving the energy efficiency of the existing building stock: a critical review of commercial and institutional buildings. Renewable and Sustainable Energy Reviews, 53, 1032-1045. http://dx.doi.org/10. 1016/j.rser.2015.09.084.

Süsser, D., Döring, M., \& Ratter, B. M. W. (2017). Harvesting energy: place and local entrepreneurship in community-based renewable energy transition. Energy Policy, 101, 332-341. http://dx.doi.org/10.1016/j.enpol.2016.10.018.

Sovacool, B. K., \& Geels, F. W. (2016). Further reflections on the temporality of energy transitions: a response to critics. Energy Research \& Social Science, 22, 232-237. http://dx.doi.org/10.1016/j.erss.2016.08.013.

Sperling, K., Hvelplund, F., \& Mathiesen, B. V. (2011). Centralisation and decentralisation in strategic municipal energy planning in Denmark. Energy Policy, 39, 1338-1351. http://dx.doi.org/10.1016/j.enpol.2010.12.006.

Wilson, E. (2006). Adapting to climate change at the local level: the spatial planning response. Local Environment, 11, 609-625. http://dx.doi.org/10.1080/ 13549830600853635.

EDP distribuição (2014). Electricity distribution system. 